\title{
DNA Homology and Taxonomy of Pseudomonas and Xanthomonas
}

\author{
BY J. DE LEY, I. W. PARK, R. TIJTGAT, \\ AND J. VAN ERMENGEM \\ Laboratory for Microbiology, Faculty of Sciences, \\ State University, Gent, Belgium
}

(Received 5 July 1965)

\begin{abstract}
SUMMARY
The relatedness between several nomen species of the Pseudomonas$X$ anthomonas group and some other organisms was numerically fixed through DNA homology and DNA base composition. For Pseudomonas the numerically analysed strains proposed by Lysenko as neotypes were used. The mean $\%(\dot{G}+\mathrm{C})$ was in the range $60-67 \cdot 5$. ${ }^{14} \mathrm{C}-\mathrm{DNA}$ from either Pseudomonas fluorescens or $P$. putida was hybridized with DNA from 17 different species centres and the DNA homology was in the range 50-100\%. Genetic species differentiation in the genus Pseudomonas seems justified. In three border cases $(\boldsymbol{P}$. iodinum, $\boldsymbol{P}$. diminuta and $\boldsymbol{P}$. atlantica) DNA homology was only $28-50 \%$, so the inclusion of these organisms in the genus Pseudomonas is uncertain. The species centres $\boldsymbol{P}$. pavonacea and $\boldsymbol{P}$. rubescens are omitted from the genus Pseudomonas because of their very low DNA homology and aberrant DNA base composition. Twentyeight nomen species of $\boldsymbol{X}$ anthomonas all form a narrow group in the range 63.5-69\% $(\mathrm{G}+\mathrm{C})$. With two exceptions DNA homology with a median strain Xanthomonas pelargonii was always over $75 \%$ and frequently nearly complete. ${ }^{14} \mathrm{C}-\mathrm{DNA}$ from $\boldsymbol{P}$. fluorescens hybridized with $\bar{X}$ anthomonas-DNA to the same extent as with the pseudomonads proper. The Xanthomonas cluster overlapped perfectly with part of the Pseudomonas group. It is proposed therefore to gather all xanthomonads in a single genetic species $\boldsymbol{P}$. campestris. This is such a dense cluster that the preservation of separate species names for the border cases seems undesirable. About one half to two-thirds of Pseudomonas- and Xanthomonas-DNA is identical. The genera Rhizobium, Azotobacter and Azomonas appeared to be rather closely related to Pseudomonas since they shared some $40-50 \%$ of their DNA. The genus Serratia appeared to be more closely related to Pseudomonas than to Escherichia. The genera Gluconobacter, Acetobacter, Serratia and Escherichia shared some 20-30\% DNA with Pseudomonas, but Bacillus-DNA was almost entirely different. From a comparison between DNA homology and taximetric similarity, it appeared that most pseudomonads would not contain unused genes. The advantages of a classification based on $\%(\mathbf{G}+\mathbf{C})$ and DNA homology are obvious.
\end{abstract}

\section{INTRODUCTION}

Assuming a molecular weight of $6 \times 10^{9}$ for bacterial chromosomal DNA and about $10^{3}$ base pairs per cistron, it can be estimated that a bacterial genome contains some $10^{4}$ cistrons. The present orthodox classification, as exemplified in 
Bergey's Manual (1957), is built on phenotypic data, quite often on very few, thus encompassing only a minute fraction of the total genome. Numerical analysis is a much better approach to determine relatedness: because up to 200 characters may be used, and assuming that an average of 5-10 cistrons is involved in each character, it can be estimated that some $\mathbf{1 0 - 2 0} \%$ of the genome is detected. Many properties still remain hidden and classification could be improved considerably by determining the degree of identity of chromosomal DNA. This is possible through the DNA-hybridization method of McCarthy \& Bolton (1963). The present paper is a molecular biological approach to a more rational classification based on two DNA parameters: (i) base composition, expressed as a mean molar (guanine + cytosine) content $(\%(\mathrm{G}+\mathrm{C}))$, and (ii) homology. It is likewise an attempt for a better understanding of the ill-defined concept of species and genus in bacteriology. As a model system we sought to clarify the relatedness between several nomen species within Pseudomonas and Xanthomonas, as well as the relatedness between the two groups. We selected the collection of Pseudomonas strains from Lysenko (1961) because their taximetric similarity is well known. By comparing DNA homology and taximetric similarity of the same strains, one might also detect whether a fraction of the genome remains unused. For Xanthomonas some 60-odd nomen species are listed in Bergey's Manual (1957). With nine of them 80-100\% of their DNA is identical and they can be gathered in one genetic species, $X$. campestris (Friedman \& De Ley, 1965; De Ley \& Friedman, 1965). These investigations were extended in the present paper with a total of 28 different nomen species and their DNA homology with a representative Pseudomonas was determined. The degree of DNA homology was determined between the pseudomonads and representatives of a few other genera in the same $\%(\mathbf{G}+\mathbf{C})$ range (Gluconobacter, Acetobacter, Serratia, Rhizobium, Azotobacter and Azomonas) and in a different $\%(\mathrm{G}+\mathrm{C})$ range (Escherichia and Bacillus).

\section{METHODS}

Organisms used. All organisms used are shown in Table 1. The strains of Pseudomonas (except strain PR 107) were received from Dr O. Lysenko, Laboratory of Insect Pathology, Prague; the strain numbers are from the Culture Collection of Entomogenous Bacteria (CCEB), Prague. Strain 293 was originally thought to be $P$. synxantha (Lysenko, 1961) but was later identified as Serratia marcescens (Catalogue of Cultures, 1964). Strain 607 was only tentatively labelled as $P$. synxantha (O. Lysenko, personal communication). All xanthomonads were received from Professor M. P. Starr from the International Collection of Phytopathogenic Bacteria, Department of Bacteriology, University of California, Davis, California. The strain PR 107 was received as Pseudomonas (Xanthomonas?) rimaefaciens. The results given in the present paper show it to belong in Pseudomonas. The Rhizobium strains were received from Professor C. Bonnier, Institut Agronomique de l'État, Gembloux, Belgium, and the Azotobacter strain was obtained from the National Collection of Industrial Bacteria (NCIB), Aberdeen, Scotland. In a future paper we shall bring evidence to show why the generic name Azomonas (Baillie, Hodgkiss \& Norris, 1962), which is used in Table 1, is a better choice for strain 9218. The strains of Gluconobacter, Acetobacter, Escherichia and Bacillus were from our departmental collection. 
Cultivation techniques. All organisms were grown on solid media in Roux flasks. The Pseudomonas and Serratia strains were grown for about 2 days at $30^{\circ}$ on a medium containing $(\%, w / v)$ : Proteose peptone 1, yeast extract (Nederl. Gist-en Spiritusfabriek, Brugge, Belgium) $0 \cdot 1, \mathrm{NaCl} 0 \cdot 5$, glucose 1 and agar 2.5. The xanthomonads were grown at $25^{\circ}$ for 3-4 days on a medium, selected for good growth and low polysaccharide production, and containing ( $\%, w / v)$ : beef extract (Oxoid) 1 , Difco-peptone $1, \mathrm{NaCl} \mathbf{0} \cdot 5$, agar $2 \cdot 5$. The acetic acid bacteria were grown for 3 days at $30^{\circ}$ on $(\%, w / v)$ : glucose $5, \mathrm{CaCO}_{3} 3$, yeast extract 1 , agar $2 \cdot 5$. Rhizobium was grown for 3 days at $25^{\circ}$ on $(\%, w / v)$ : mannitol $1, \mathrm{NaCl} 0 \cdot 02, \mathrm{~K}_{2} \mathrm{HPO}_{4} 0 \cdot 05, \mathrm{MgSO}_{4}$. $7 \mathrm{H}_{2} \mathrm{O} 0 \cdot 02, \mathrm{CaSO}_{4} \cdot 2 \mathrm{H}_{2} \mathrm{O} 0 \cdot 01, \mathrm{CaCO}_{3} \mathbf{0} \cdot 01$, yeast extract 0.1, agar 2.5. Azotobacter and Azomonas were grown for 2 days at $30^{\circ}$ on $(\%, w / v)$ : glucose $1, \mathbf{K}_{2} \mathrm{HPO}_{4} \mathbf{0} \cdot 1$, $\mathrm{MgSO}_{4} .7 \mathrm{H}_{2} \mathrm{O} 0.02, \mathrm{CaCO}_{3} \mathbf{0} \cdot 1, \mathrm{NaCl} 0 \cdot 02$, Na molybdate 0.0005 , agar 2.5. Escherichia coli and Bacillus subtilis were grown for 1-2 days at $30^{\circ}$ on $(\%, \mathrm{w} / \mathrm{v}):$ peptone 0.5 , yeast extract 0.25 and agar 2.5 .

Cultivation of ${ }^{14} \mathrm{C}$-labelled strains. Xanthomonas pelargonii $\mathbf{P} 121$ was selected because its $\%(G+C)$ is in the middle of the group. For the same reason it had been used in previous hybridization experiments (Friedman \& De Ley, 1965; De Ley \& Friedman, 1965). Pseudomonas putida 520 and $P$. fluorescens 488 were selected because their \% $(\mathrm{G}+\mathrm{C})$ (Table 1) and taximetric similarity (Lysenko, 1961) put them centrally in the Pseudomonas group. The organisms were grown at $30^{\circ}$ on a reciprocal shaker in liquid medium in 11 . Erlenmeyer flasks containing $200 \mathrm{ml}$. each of the medium. The medium contained $(\%, w / v)$ proteose peptone (Oxoid) 1 , yeast extract $0 \cdot 1, \mathrm{NaCl} 0 \cdot 5$, glucose 1 , at $\mathrm{pH} 7 \cdot 2$. At the beginning of the log phase a sterile solution with $100 \mu \mathrm{c}$. uracil-2- ${ }^{14} \mathrm{C} / 200 \mathrm{ml}$. of medium was added and the organisms were allowed to grow until the end of the log phase. They were harvested and washed several times in 0.01 M-phosphate buffer ( $\mathrm{pH} \mathrm{6)}$.

SSC buffer contained $0.15 \mathrm{M}-\mathrm{NaCl}$ and $0.15 \mathrm{M}$-trisodium citrate at $\mathrm{pH} \mathrm{7.0.} \mathrm{It} \mathrm{was}$ also made up at quarter strength $(0.25 \times \mathrm{SSC})$ and double strength $(2 \times \mathrm{SSC})$ etc.

Preparation of $D N A$ was done according to Marmur (1961). Its molecular weight was in the range 5-10 $\times 10^{6}$. High molecular weight denatured DNA agar was prepared according to Bolton \& McCarthy (1962), with the exception that it was heated at $107-110^{\circ}$ in $0.25 \times \mathrm{SSC}$ buffer instead of at $100^{\circ}$, because the 'melting point' of Pseudomonas- and Xanthomonas-DNA is rather high. Depending on the strain $1 \mathrm{~g}$. of wet agar contained about $500 \mu \mathrm{g}$. DNA. ${ }^{14} \mathrm{C}$-DNA was sheared by passing it through the French pressure cell at 12,000 p.s.i. Its molecular weight was about $3 \times 10^{5}$. It was denatured at $107-110^{\circ}$ in $0 \cdot 1-0 \cdot 2 \times \mathrm{SSC}$ buffer for $5 \mathrm{~min}$. followed by quick cooling in ice. Its final concentration was $50 \mu \mathrm{g} . / \mathrm{ml} .2 \times \mathrm{SSC}$ buffer. The specific activity was $680 \mathrm{cpm} . / \mathrm{min} / \mu \mathrm{g} .{ }^{14} \mathrm{C}-\mathrm{DNA}$ from $X$. pelargonii, $336 \mathrm{cpm} . / \mathrm{min} . / \mu \mathrm{g}$. ${ }^{14} \mathrm{C}-\mathrm{DNA}$ from $P$. fluorescens 488 and $70 \mathrm{cpm}$. $/ \mathrm{min} . / \mu \mathrm{g}$. ${ }^{14} \mathrm{C}-\mathrm{DNA}$ from $P$. putida 520.

Hybridization experiments; phosphodiesterase treatment. The method of McCarthy $\&$ Bolton (1963) was used. An amount of agar containing $350 \mu \mathrm{g}$. of high-molecular denatured DNA from different strains and $35 \mu \mathrm{g}$. of sheared denatured ${ }^{14} \mathrm{C}-\mathrm{DNA}$ from each of the three labelled strains was used. Disintegrations were counted as previously described (De Ley \& Friedman, 1965). The correction factor for self-absorption in $2 \times \mathrm{SSC}$ buffer in the conditions used was $14.4 \%$; for $0.01 \times \mathrm{SSC}$ it was negligible.

To determine the percentage of unhybridized ${ }^{14} \mathrm{C}-\mathrm{DNA}$ which adhered as loose single-stranded ends to the DNA-agar after washing with $2 \times \mathrm{SSC}$ buffer, a treat- 
Table 1. Some physical properties ('melting point' $T_{m}$; average (guanine+cytosine) content $\%(G+C)$ ) of purified $D N A$ and degree of DNA homology of several pseudomonads, xanthomonads and a ferw other groups.

The pseudomonads are the neotype species centres as proposed by Lysenko (1961). The values with * are taken from De Ley \& Friedman (1965), the values for $T_{m}$ and $\%(G+C)$ for the acetic acid bacteria are from De Ley \& Schell (1963), Rhizobium from De Ley \& Rassell (1965) and Escherichia coli from De Ley (1965). The 'melting point' $T_{m}$ was determined with the automatic recording thermal spectrophotometer (De Ley \& Van Muylem, 1963). The $\%(G+C)$ was calculated from $T_{m}$ according to Marmur \& Doty (1962). The method of McCarthy \& Bolton (1963) was followed for the hybridization experiments.

\section{Strain}

number

$\begin{aligned} & \text { Pseudomonas } \\ \mathbf{3 3 8} & \text { geniculata } \\ \mathbf{5 1 3} & \text { diminuta } \\ \mathbf{4 8 1} & \text { aeruginosa } \\ \mathbf{5 0 6} & \text { atlantica } \\ \mathbf{P R} 107 & \text { rimaefaciens } \\ \mathbf{3 8 0} & \text { ovalis } \\ \mathbf{5 2 2} & \text { stutzeri } \\ \mathbf{5 2 0} & \text { putida } \\ \mathbf{5 5 9} & \text { chlororaphis } \\ \mathbf{5 1 8} & \text { aureofaciens } \\ \mathbf{4 8 8} & \text { fluorescens } \\ \mathbf{5 2 5} & \text { denitrificans } \\ \mathbf{6 0 7} & \text { synxantha } \\ \mathbf{3 8 7} & \text { fragi } \\ \mathbf{5 1 2} & \text { iodinum } \\ \mathbf{3 8 1} & \text { taetrolens } \\ \mathbf{5 1 9} & \text { rubescens } \\ \mathbf{5 3 3} & \text { pavonacea } \\ & \text { Xanthomonas } \\ \mathbf{C 1 4 4} & \text { celebensis } \\ \mathbf{H 1 1 0} & \text { hyacinthi } \\ \mathbf{c 1 2 9} & \text { campestris }\end{aligned}$

$T_{m}$

$\%(\mathbf{G}+\mathbf{C})$

$97 \cdot 0$

96.9

$96 \cdot 7$

$96 \cdot 6$

$96 \cdot 6$

95.9

$95 \cdot 8$

95-4.

95.3

95.1

94.95

94:9

94:35

94.2

94. 05

93.85

$\mathbf{8 8 \cdot 2 5}$

88.05

$97 \cdot 7$

$97 \cdot 4$

$\mathbf{9 7 \cdot 3}$

\begin{tabular}{|l|}
\hline $67 \cdot 5$ \\
$67 \cdot 3$ \\
$66 \cdot 8$ \\
$66 \cdot 5$ \\
$66 \cdot 5$ \\
$64 \cdot 8$ \\
$64 \cdot 5$ \\
$63 \cdot 5$ \\
$63 \cdot 3$ \\
$62 \cdot 8$ \\
$62 \cdot 4$ \\
$62 \cdot 3$ \\
$61 \cdot 0$ \\
$60 \cdot 6$ \\
$60 \cdot 2$ \\
\hline $59 \cdot 8$ \\
$46 \cdot 1$ \\
$45 \cdot 6$ \\
\hline $69 \cdot 2$ \\
\hline $68 \cdot 5$ \\
$68 \cdot 2$ \\
\hline
\end{tabular}

Hybridization with ${ }^{14}$ C-DNA from $P$. fluorescens 488

$\overbrace{\begin{array}{c}\% \\ { }^{4} \mathrm{C}-\mathrm{DNA}\end{array}}^{P \text { P }}$

$\%$

${ }^{14}$ C-DNA

bound

relative

to $P$.

fluorescens

$35 \cdot 8 \quad 64$

$\begin{array}{ll}35 \cdot 8 & 64 \\ 21 \cdot 5 & 38\end{array}$

$21 \cdot 5$

$35 \cdot 4$

$15 \cdot 7$

$35 \cdot 8$

$65 \cdot 0$

$42 \cdot 4$

$39 \cdot 6$

$36 \cdot 5$

$30 \cdot 8$

$56 \cdot 1$

35.4

$52 \cdot 3$

$41 \cdot 0$

$25 \cdot 3$

43.8

1.7

$\mathbf{3 . 9}$

38

63

28

116

$75 \cdot 5$

$70 \cdot 5$

65

55

100

63
$\mathbf{9 3} \cdot 5$

73

45

78

$\mathbf{3}$

$18 \cdot 5$

33.1

33

59
Hybridization with

${ }^{14}$ C-DNA from

P. putida 520

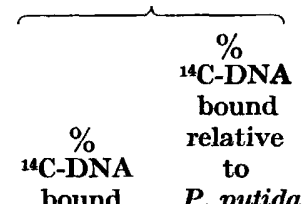

Hybridization with

${ }^{14} \mathrm{C}$-DNA from

$X$. pelargonii $\mathrm{P} 121$

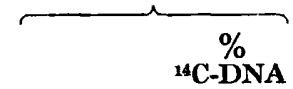

bound

\% $\%$

relative

to

$\begin{array}{lll}\text { P.putida } & \text { bound } & X \text {. pelargonii }\end{array}$

\begin{tabular}{|c|c|c|c|}
\hline $28 \cdot 5$ & 51 & - & - \\
\hline $21 \cdot 2$ & 38 & - & $69^{*}$ \\
\hline 34.0 & 61 & - & - \\
\hline $16 \cdot 2$ & 29 & - & $75^{*}$ \\
\hline - & - & $33 \cdot 5$ & 55 \\
\hline $37 \cdot 7$ & $67 \cdot 5$ & - & $63^{*}$ \\
\hline $33 \cdot 5$ & 60 & - & - \\
\hline $55 \cdot 8$ & 100 & $32 \cdot 8$ & 54 \\
\hline $34 \cdot 6$ & 62 & - & - \\
\hline
\end{tabular}


Table 1 (continued)

\begin{tabular}{|c|c|}
\hline $\begin{array}{l}\text { Strain } \\
\text { number }\end{array}$ & Organism \\
\hline $\begin{array}{l}\text { T7 } \\
\text { M16 }\end{array}$ & $\begin{array}{l}\text { translucens } \\
\text { maculafoliagardeniae }\end{array}$ \\
\hline $\mathrm{T} 20$ & $\begin{array}{l}\text { maculafonagaraenae } \\
\text { tamarindi }\end{array}$ \\
\hline A121 & alfalfae \\
\hline н1 & hederae \\
\hline B3 & begoniae \\
\hline c104 & carotae \\
\hline P10 & pruni \\
\hline $\mathbf{L} 1$ & lespedezae \\
\hline c5 & corylina \\
\hline P121 & pelargonii \\
\hline v136 & vesicatoria \\
\hline J107 & juglandis \\
\hline 13 & incanae \\
\hline P 137 & poinsettiaecola \\
\hline P162 & phaseoli \\
\hline c110 & cassavae \\
\hline v118 & vignicola \\
\hline P5 & papavericola \\
\hline в 109 & beticola \\
\hline м2 & malvacearum \\
\hline $\mathbf{L 4}$ & lactucae \\
\hline $\mathbf{v 2 4}$ & vasculorum \\
\hline T11 & taraxaci \\
\hline & geranii \\
\hline 8131 & Gluconobacter oxydans (viscosus) \\
\hline 20 & Acetobacter aceti (liquefaciens) \\
\hline 293 & Serratia marcescens \\
\hline 15 & Rhizobium meliloti \\
\hline & Rhizobium leguminosarum \\
\hline 9125 & Azotobacter chroococcum \\
\hline 9128 & Azomonas macrocytogenes \\
\hline B & Escherichia coli \\
\hline BQ2 & $\begin{array}{l}\text { Bacillus subtilis } \\
\text { Agar }\end{array}$ \\
\hline
\end{tabular}

\begin{tabular}{|c|c|c|c|c|c|c|c|}
\hline \multirow[b]{2}{*}{$T_{m}$} & \multirow[b]{2}{*}{$\%(\mathbf{G}+\mathrm{C})$} & \multicolumn{2}{|c|}{$\begin{array}{c}\text { Hybridization with } \\
{ }^{14} \text { C-DNA from } \\
\text { P. fluorescens } 488\end{array}$} & \multicolumn{2}{|c|}{$\begin{array}{c}\text { Hybridization with } \\
{ }^{14} \mathrm{C}-\mathrm{DNA} \text { from } \\
\text { P. putida } 520\end{array}$} & \multicolumn{2}{|c|}{$\begin{array}{l}\text { Hybridization with } \\
{ }^{14} \text { C-DNA from } \\
X \text {. pelargonii } P 121\end{array}$} \\
\hline & & $\begin{array}{c}\% \\
{ }^{14} \text { C-DNA } \\
\text { bound }\end{array}$ & $\begin{array}{c}\% \\
{ }^{14} \mathrm{C}-\mathrm{DNA} \\
\text { bound } \\
\text { relative } \\
\text { to } P \text {. } \\
\text { fluorescens }\end{array}$ & $\begin{array}{c}\text { \% } \\
{ }^{14} \text { C-DNA } \\
\text { bound }\end{array}$ & $\begin{array}{c}\% \\
{ }^{14} \mathrm{C}-\mathrm{DNA} \\
\text { bound } \\
\text { relative } \\
\text { to } \\
P \text {. putida }\end{array}$ & $\begin{array}{c}\% \\
{ }^{14} \mathrm{C}-\mathrm{DNA} \\
\text { bound }\end{array}$ & $\begin{array}{c}\% \\
{ }^{4} \mathrm{C}-\mathrm{DNA} \\
\text { bound } \\
\text { relative } \\
\text { to } \\
X . \text { pelargonii }\end{array}$ \\
\hline $97 \cdot 2$ & 68.0 & $\mathbf{3 4 \cdot 8}$ & 62 & - & - & $47 \cdot 2$ & $77 \cdot 5$ \\
\hline $97 \cdot 1$ & $67 \cdot 7$ & $39 \cdot 8$ & 71 & - & - & $50 \cdot 6$ & $\mathbf{8 3}$ \\
\hline $97 \cdot 1$ & 67.7 & - & - & - & - & - & $104^{*}$ \\
\hline $96 \cdot 9$ & $67 \cdot 3$ & 33.7 & 60 & - & - & $54 \cdot 1$ & 89 \\
\hline $96 \cdot 9$ & $67 \cdot 3$ & - & - & - & - & - & $87 *$ \\
\hline $96 \cdot 85$ & $67 \cdot 1$ & - & - & - & - & - & $92^{*}$ \\
\hline $96 \cdot 8$ & $67 \cdot 0$ & - & - & - & - & - & $114^{*}$ \\
\hline $96 \cdot 7$ & $66 \cdot 8$ & $28 \cdot 6$ & 51 & - & - & $48 \cdot 7$ & 80 \\
\hline $96 \cdot 65$ & $66 \cdot 6$ & $33 \cdot 7$ & 60 & - & - & 56 & 92 \\
\hline $96 \cdot 65$ & $66 \cdot 6$ & $41 \cdot 0$ & 73 & - & - & $52 \cdot 3$ & 86 \\
\hline $96 \cdot 6$ & $66 \cdot 5$ & $31 \cdot 4$ & 56 & $27 \cdot 6$ & $49 \cdot 5$ & $60 \cdot 9$ & 100 \\
\hline $96 \cdot 55$ & $66 \cdot 4$ & $25 \cdot 0$ & 44.5 & - & - & $52 \cdot 3$ & 86 \\
\hline $96 \cdot 5$ & $66 \cdot 3$ & - & - & - & - & - & 93* \\
\hline $96 \cdot 5$ & $66 \cdot 3$ & $27 \cdot 5$ & 49 & - & - & 48.7 & 80 \\
\hline $96 \cdot 4$ & $66 \cdot 0$ & $29 \cdot 7$ & 53 & - & - & $50 \cdot 9$ & $83 \cdot 5$ \\
\hline $96 \cdot 4$ & $66 \cdot 0$ & 29.7 & 53 & - & - & $45 \cdot 6$ & 75 \\
\hline $96 \cdot 35$ & 65.9 & $37 \cdot 6$ & 67 & - & - & $55 \cdot 3$ & 91 \\
\hline $96 \cdot 3$ & 65.7 & $32 \cdot 5$ & 58 & - & - & $58 \cdot 3$ & 96 \\
\hline $96 \cdot 3$ & $65 \cdot 7$ & $25 \cdot 8$ & 46 & - & - & $48 \cdot 7$ & 80 \\
\hline $96 \cdot 3$ & 65.7 & $26 \cdot 4$ & 47 & - & - & $46 \cdot 9$ & 77 \\
\hline $96 \cdot 25$ & $65 \cdot 6$ & $25 \cdot 8$ & 46 & - & - & $37 \cdot 2$ & 61 \\
\hline $96 \cdot 0$ & $65 \cdot 1$ & $27 \cdot 0$ & 48 & - & - & 56.7 & 93 \\
\hline $95 \cdot 9$ & 64.8 & $25 \cdot 3$ & 45 & - & - & $46 \cdot 3$ & 76 \\
\hline $95 \cdot 7$ & 64.3 & $27 \cdot 0$ & 48 & - & - & $54 \cdot 4$ & $89 \cdot 5$ \\
\hline $95 \cdot 4$ & 63.5 & $25 \cdot 8$ & 46 & - & - & $53 \cdot 2$ & $87 \cdot 5$ \\
\hline $95 \cdot 35$ & $63 \cdot 4$ & $11 \cdot 2$ & 20 & $10 \cdot 1$ & 18 & - & 23* \\
\hline $95 \cdot 6$ & 64.0 & $19 \cdot 1$ & 34 & $15 \cdot 6$ & 28 & - & $\mathbf{3 7 *}$ \\
\hline $93 \cdot 9$ & 59.9 & $20 \cdot 2$ & 36 & $17 \cdot 3$ & 31 & - & - \\
\hline 95.0 & $62 \cdot 5$ & $21 \cdot 6$ & $38 \cdot 5$ & - & - & - & - \\
\hline $93 \cdot 6$ & $59 \cdot 1$ & $31 \cdot 4$ & 56 & - & - & - & - \\
\hline $96 \cdot 4$ & 66.0 & - & - & $27 \cdot 9$ & 50 & - & - \\
\hline 93·3 & $58 \cdot 4$ & - & - & 23.5 & 42 & - & - \\
\hline $90 \cdot 9$ & $52 \cdot 5$ & $16 \cdot 8$ & 30 & $9 \cdot 5$ & 17 & - & $19^{*}$ \\
\hline $88 \cdot 9$ & $47 \cdot 7$ & 3-4 & 6 & $6 \cdot 1$ & 11 & - & - \\
\hline- & - & 0.5 & 1 & - & - & 1.2 & $\mathbf{2}$ \\
\hline
\end{tabular}


ment with dogfish phosphodiesterase was carried out as follows. Hybridization of DNA and washing of the agar column with ten $10 \mathrm{ml}$. fractions of $2 \times \mathrm{SSC}$ buffer at $60^{\circ}$ was carried out as usual. All buffer was then eliminated with slight air pressure until the agar was still just moist. The temperature of the column was brought down to $37^{\circ}$. The agar was washed with $5 \mathrm{ml}$. of PD buffer (containing $1.5 \times 10^{-3}$ $\mathrm{M}-\mathrm{MnCl}_{2} \mathbf{0} \cdot 01 \mathrm{M}$-tris, $0.14 \mathrm{M}-\mathrm{NaCl} ; \mathrm{pH} \mathrm{8.0)}$ and the eluate was collected. 1/50 diluted enzyme in $1 \mathrm{ml}$. buffer was added to the DNA agar and incubated at $37^{\circ}$ for $1 \mathrm{hr}$, upon which the column was again washed at $60^{\circ}$ with ten $10 \mathrm{ml}$. fractions $2 \times \mathrm{SSC}$ buffer and samples taken for counting. The last step consisted in increasing the column temperature to $75^{\circ}$ and washing with 10-15 10-ml. fractions of $0.01 \times$ SSC buffer.

Determination of the average base composition and the compositional distribution of the DNA molecules. Both values were calculated from the thermal denaturation curve of pure DNA. The latter was determined with the automatic recording thermal spectrophotometer as previously described (De Ley \& Van Muylem, 1963). The mean base composition, expressed as $\%(\mathbf{G}+\mathrm{C})$, was calculated from the 'melting point' $\boldsymbol{T}_{m}$ with Marmur \& Doty's (1962) formula $\%(\mathrm{G}+\mathrm{C})=\left(\boldsymbol{T}_{m}-69 \cdot 3\right) / 0 \cdot 41$. A previous paper chromatographic check on this formula (De Ley \& Schell, 1963) showed it to be valid in the range used. The standard deviation $\sigma$ of the compositional distribution around the average $\%(G+C)$ was calculated according to Doty, Marmur \& Sueoka (1959).

\section{RESULTS}

The main results are summarized in Table 1.

DNA base composition. The pseudomonads are divided into two groups. The largest has a $\boldsymbol{T}_{m}$ in the range of $93.8^{\circ}$ to $97.0^{\circ}$ or a $\%(\mathrm{G}+\mathrm{C})$ from 59.8 to 67.5 . The other group comprises only $P$ rubescens 519 and $P$. pavonacea 533 with a quite different $\%(\mathrm{G}+\mathrm{C})$ of about $46 \%$. The latter strains are thus genetically different from the main group. The $\%(\mathrm{G}+\mathrm{C})$ range of the main group agrees very well with values of a few strains reported by Colwell \& Mandel (1964), De Ley \& Friedman (1965), Marmur, Falkow \& Mandel (1963).

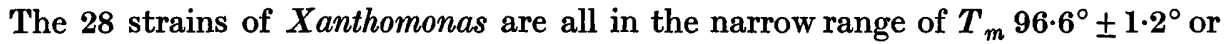
a $\%(G+C)$ from $63 \cdot 5$ to $69 \cdot 2$. These values confirm the previous conclusion from this laboratory, that these organisms form a narrow group. It may be noted that the $\%(\mathbf{G}+\mathbf{C})$ values of $\boldsymbol{X}$ anthomonas overlap with the higher range of Pseudomonas and that no distinction can be made between these groups on the basis of base composition alone. The $\boldsymbol{T}_{m}$ of Serratia marcescens 293 falls completely within the range of other serratias (Colwell \& Mandel, 1965), although it might belong to a slightly aberrant subgroup. It is noticeable that the $\%(G+C)$ from Serratia overlaps with the lower range of $P$ seudomonas.

Compositional distribution of DNA molecules. Most of the pseudomonads and all xanthomonads have a $\sigma$ value between 0 and 1 with an average of 0.3 , a value which confirms our previous findings (De Ley \& Van Muylem, 1963). The unusually high value of 2.5 for Pseudomonas iodinum is another argument that this strain possibly does not belong in Pseudomonas. The high $\sigma$ value of 3.0 for Serratia marcescens 293 conforms to the values of 1.3-3 for other Enterobacteriaceae (De Ley \& Van Muylem, 1963; De Ley, 1965). A word of caution is required on the calculation of 
Table 2. Determination of the fraction of single-stranded ${ }^{14} C-D N A$, attached to DNA agar, which remains unhybridized.

\begin{tabular}{|c|c|c|c|c|c|c|c|c|}
\hline \multirow[b]{2}{*}{ Species } & \multirow[b]{2}{*}{$\begin{array}{c}\text { Total c.p.m.* } \\
\text { in } \\
\text { wash }\end{array}$} & \multirow[b]{2}{*}{$\begin{array}{c}\text { Total c.p.m. } \\
\text { released by } \\
\text { phospho- } \\
\text { diesterase } \uparrow\end{array}$} & \multirow[b]{2}{*}{$\begin{array}{c}\text { Total c.p.m. } \\
\text { retained on } \\
\text { DNA-agar } \\
\text { after } \\
\text { phospho- } \\
\text { diesterase }\end{array}$} & \multirow[b]{2}{*}{$\begin{array}{l}\% \text { labelled } \\
\text { DNA } \\
\text { released by } \\
\text { phospho- } \\
\text { diesterase }\end{array}$} & \multicolumn{2}{|c|}{ With phosphodiesterase } & \multicolumn{2}{|c|}{ Without phosphodiesterase } \\
\hline & & & & & $\begin{array}{l}\% \text { labelled } \\
\text { DNA } \\
\text { bound }\end{array}$ & $\begin{array}{c}\% \text { labelled } \\
\text { DNA } \\
\text { bound } \\
\text { relative to } \\
P . \text { fluorescens }\end{array}$ & $\begin{array}{c}\% \text { labelled } \\
\text { DNA } \\
\text { bound }\end{array}$ & $\begin{array}{c}\text { \% labelled } \\
\text { DNA } \\
\text { bound } \\
\text { relative to } \\
\text { P. fluorescens }\end{array}$ \\
\hline P. fluorescens & 4736 & 744 & 4975 & $7 \cdot 1$ & $47 \cdot 6$ & $100 \ddagger$ & 54:7 & $100 \ddagger$ \\
\hline$P$. aeruginosa & 7150 & 458 & 3315 & $4 \cdot 2$ & $\mathbf{3 0} \cdot \mathbf{3}$ & $63 \cdot 7$ & $\mathbf{3 4} \cdot 5$ & $61 \cdot 4$ \\
\hline $\boldsymbol{P}$, taetrolens & 6212 & 755 & 3930 & $6 \cdot 9$ & $36 \cdot 1$ & $75 \cdot 8$ & $43 \cdot 0$ & 76.5 \\
\hline P. chlororaphis & 7184 & $\mathbf{3 5 5}$ & $\mathbf{3 0 9 0}$ & $\mathbf{3 \cdot 3}$ & $29 \cdot 1$ & $61 \cdot 1$ & $32 \cdot 4$ & $57 \cdot 7$ \\
\hline P. stutzeri & $\mathbf{5 8 0 0}$ & 194 & 3825 & $\mathbf{2} \cdot \mathbf{0}$ & $39 \cdot 0$ & $81 \cdot 9$ & $41 \cdot 0$ & $73 \cdot 0$ \\
\hline & $\begin{array}{l}* \text { C.p.m. }= \\
\dagger \text { The phosp } \\
\ddagger \text { All values } \\
\text { The meth }\end{array}$ & $\begin{array}{l}\text { ounts per min } \\
\text { lodiesterase tr } \\
\text { relative to } P \\
\text { d of McCarth }\end{array}$ & $\begin{array}{l}\text { arescens } 488, \\
\text { Bolton (196 }\end{array}$ & $\begin{array}{l}\mathrm{h} \text { is taken } \\
\text { is followed }\end{array}$ & $\begin{array}{l}0 \% . \\
\text { he hybric }\end{array}$ & ther. & & \\
\hline
\end{tabular}


the $\sigma$ value according to Doty et al. (1959). When the compositional distribution is calculated from this $\sigma$ value with, for example, the strains H 110, P121 and G1, it appears that these strains would have very few DNA molecules in common, but the hybridization experiments show that most of the DNA molecules are identical. This means that the overlapping of the compositional distribution curves must be considerable, and thus that the $\sigma$ values are too small because the correction factor of $3^{\circ} 0$, introduced by Doty et al. (1959), is too great. The best fit with our experimental data is obtained when no correction at all is applied; this means also that all $\sigma$ values, calculated from thermal denaturation curves, including those mentioned above, would be some $7 \cdot 5 \%(G+C)$ too small.

Table 3. Comparison between DNA homology and taximetric similarity of several strains of Pseudomonas.

The former values are from Table 1 and the latter, for the same strains, are from Lysenko (1961). Values indicated by * are put as $100 \%$.

\begin{tabular}{|c|c|c|c|c|}
\hline \multirow[b]{2}{*}{ Species } & \multicolumn{2}{|c|}{$\begin{array}{c}\text { Relative to } \\
P \text {. putida } \mathbf{5 2 0}\end{array}$} & \multicolumn{2}{|c|}{$\begin{array}{l}\text { Relative to } \\
\text { P. fluorescens } 488\end{array}$} \\
\hline & $\begin{array}{c}\text { \% DNA } \\
\text { homology }\end{array}$ & $\begin{array}{c}\% \text { taximetric } \\
\text { similarity }\end{array}$ & $\begin{array}{c}\% \text { DNA } \\
\text { homology }\end{array}$ & $\begin{array}{c}\% \text { taximetric } \\
\text { similarity }\end{array}$ \\
\hline P. geniculata & 51 & 44 & 64 & 62 \\
\hline P. diminuta & 38 & 61 & 38 & 62 \\
\hline P. aeruginosa & 61 & 73 & 63 & 72 \\
\hline P. atlantica & 29 & $\mathbf{5 0}$ & 28 & 56 \\
\hline P. ovalis & $67 \cdot 5$ & 81 & 116 & 77 \\
\hline P. stutzeri & 60 & 52 & $77 \cdot 5$ & 68 \\
\hline P. putida & $100 *$ & $100^{*}$ & $70 \cdot 5$ & 78 \\
\hline P. chlororaphis & 62 & 80 & 65 & 86 \\
\hline P. aureofaciens & 50 & 75 & 55 & 79 \\
\hline P. fluorescens & 83 & 78 & $100 *$ & $100^{*}$ \\
\hline P. denitrificans & 77 & 65 & 63 & 59 \\
\hline P. fragi & 64 & 66 & 73 & 69 \\
\hline$P$. iodinum & 49 & 65 & 45 & 59 \\
\hline P. taetrolens & $\mathbf{5 8 \cdot 5}$ & 58 & 78 & 68 \\
\hline P. rubescens & 6 & 46 & $\mathbf{3}$ & 64 \\
\hline P. pavonacea & 10 & 50 & 7 & 48 \\
\hline
\end{tabular}

DNA-hybridization experiments. Hybridization with either Pseudomonas fluoreścens 488 or $\boldsymbol{P}$. putida 520 shows that all pseudomonads fall into two distinct groups. The low $\%(\mathrm{G}+\mathrm{C})$ strains $\boldsymbol{P}$. rubescens and $\boldsymbol{P}$. pavonacea hybridize for only 3-10\%. The main group, made up of all the other strains, contains a few doubtful cases: $\boldsymbol{P}$. diminuta, $\boldsymbol{P}$. atlantica and $\boldsymbol{P}$. iodinum, which hybridize to the extent of 28-50\%; all other strains show a high degree of relatedness. DNA of $\boldsymbol{P}$. fluorescens $488, P$. ovalis 380 and $P$. 'synxantha' 607 appears to be almost, if not completely, identical. The degree of DNA homology of many strains is about the same with both $\boldsymbol{P}$. fluorescens and $\boldsymbol{P}$. putida. All strains of $X$ anthomonas, except $\boldsymbol{X}$. celebensis c 144, have a DNA homology of $45-73 \%$ with $P$. fluorescens, with an average of $54 \%$. This agrees closely with our previous conclusion based on a smaller collection of strains that about two-thirds of Xanthomonas-DNA is equal to PseudomonasDNA (De Ley \& Friedman, 1965).

From the hybridization of DNA from all xanthomonads with $X$. pelargonii $\mathrm{P} 121$, 
it follows that all strains, except $X$. celebensis c144 and $X$. malvacearum м2, hybridize for $75 \%$ or more, with an average for the group of $87 \%$. Nine strains out of 27 hybridize for $90-100 \%$ with $X$. pelargonii; eleven strains hybridize for $80-90 \%$ and the remaining 5 for $76-79 \%$.

Reproducibility of the method. The values for DNA homology were in most cases reproducible to within 1-6\%, although in four cases errors of 9-13\% were observed. The number of erroneous results depends on the age of the DNA preparations. High-molecular, double-stranded DNA can be preserved in good condition in concentrated solution (about 1 or more mg. DNA/ml. SSC buffer) for several months at $4^{\circ}$ with a drop of chloroform added. For reproducible results it is advisable to use freshly prepared DNA agar and sheared denatured ${ }^{14} \mathrm{C}-\mathrm{DNA}$ solution that is not over 2 weeks old.

The effect of phosphodiesterase. One set of experiments, representative for several others, is summarized in Table 2. It was invariably found that with every strain used, about $5 \%$ of the total recovery is not hybridized; this corresponds to about one-tenth of the length of a ${ }^{14} \mathrm{C}$-DNA fragment. Since this value is about the same for both the reference strain and the others under investigation, it does not affect the final conclusion on DNA homology.

\section{DISCUSSION}

An approach to a rational classification, based on two independent parameters from the genome (mean base composition and DNA homology) is represented in Figs. 1-3.

\section{Xanthomonas}

With respect to the central reference strain $X$. pelargonii $\mathrm{P} 121$, all strains (except M 2 and c 144, see below) form one tight cluster (Fig. 1). These results throw a new light on the biological relatedness between organisms and on the species concept. They show that artificial pigeon-holing in the usual orthodox classifications of this genus do not reflect reality but they corroborate the concept of a genetic species. The genus $X$ anthomonas appears not to contain about 60 sharply separated species, but to be a tight cluster of strains, each one having 75-100\% of its DNA identical with that of the central reference strain, and probably also amongst themselves. It seems to us that at least the ten strains which have over 90\% DNA similarity (campestris, tamarindi, begoniae, carotae, lespedezae, pelargonii, juglandis, cassavae, vignicola and lactucae) can no longer be regarded as separate species and should be gathered into one. In view of the tightness of the group, it seems better to regard the entire group as one biological unit, one geno-species, for which the specific epithet 'campestris' is proposed (the generic name will be discussed below). This supports a previous suggestion (Friedman \& De Ley, 1965; De Ley \& Friedman, 1965), which was made after a similar study of a smaller group. The most widely divergent strains, e.g. pelargonii and phaseoli, differ by $25 \%$ of their genome or about 2500 cistrons. Whether these organisms deserve separate species recognition is more a matter of opinion than of fact. For nomenclatural purposes it should be recalled that other organisms which differ by some $25 \%$ of their genome, such as rhesus monkey and man (Hoyer, McCarthy \& Bolton, 1964), may differ by as many as $8 \times 10^{5}$ cistrons ('total' mol. weight of mammalian DNA $2 \times 10^{12}$ and assuming 


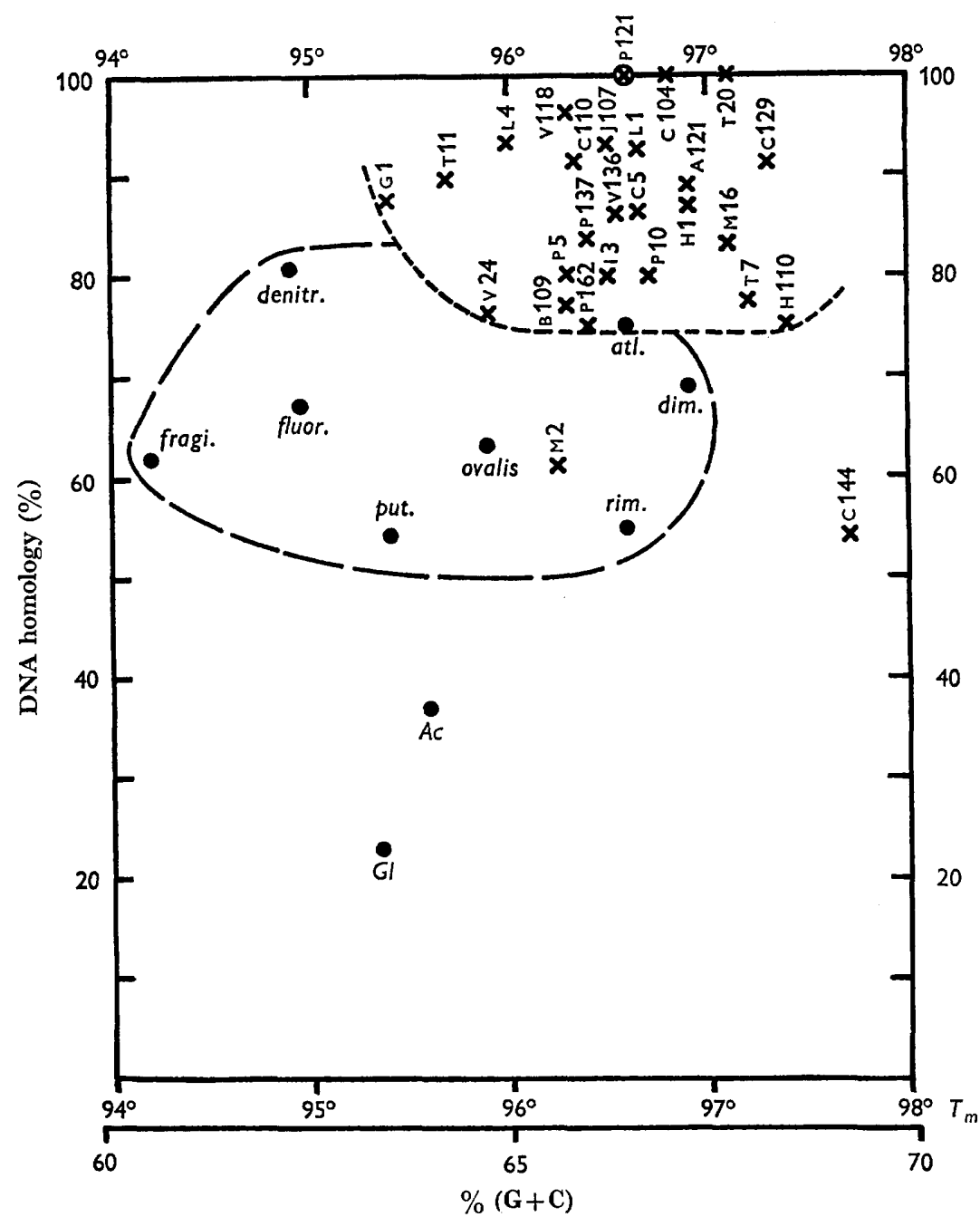

Fig. 1. Relatedness within the Xanthomonas group and between the xanthomonads and the pseudomonads, on the basis of DNA base composition and DNA homology (hybridization relative to $X$. pelargonii $\mathbf{P} 121$ ). The organisms, whose position on the map is indicated by $\times$ followed by a strain number, are named xanthomonads. The line -... shows the approximate border of the proposed genetic group Pseudomonas campestris. It is seen that strain $M 2$ and $\mathrm{c} 144$ are aberrant from the main group. The position of the named pseudomonads is indicated by 0 and the abbreviation of the species name. The named Pseudomonas group is delineated by - - . Relatedness with a strain of Acetobacter (Ac) and Gluconobacter (Gl) is given for comparison. All data from Table 1.

$10^{3}$ base pairs per cistron) and that a few thousand genes are now thought to account for the differences within the species man.

The strains malvacearum M 2 and celebensis c 144 seem to fall outside the Xanthomonas group. The former strain, however, still groups with the other xanthomonads, with respect to $\boldsymbol{P}$. fluorescens 488 . Strain c 144 is the most remote one. We believe it to be still a xanthomonad because of its alleged phytopathogenicity and because we detected the typical xanthomonas-carotenoid (absorption maxima at 464 and 


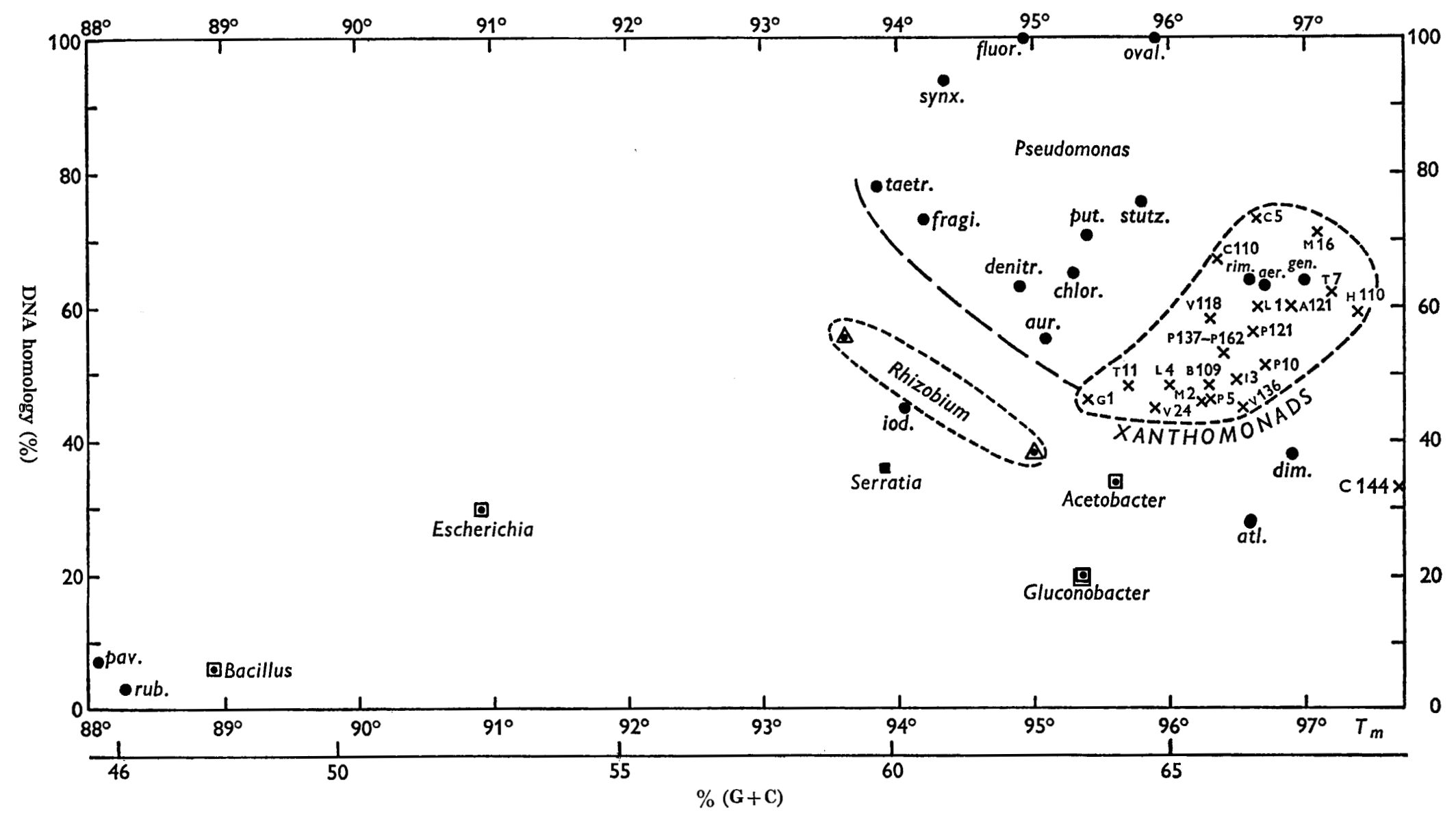

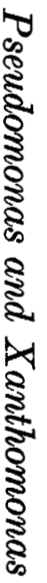

Fig. 2. Relatedness within the Pseudomonas group and between the pseudomonads, the xanthomonads and some other groups on the basis of DNA base composition and DNA homology (hybridization relative to Pseudomonas fuorescens 488). Symbols and abbreviations as in Fig. 1. The approximate relatedness of other genera is indicated by one or two strains only. 
$437 \mathrm{~m} \mu$ and a shoulder at $418 \mathrm{~m} \mu$ ) after extraction according to Starr \& Stephens (1964). Both strains might belong to separate species-centres, although it seems more likely that they are aberrant variations on the main theme. Other strains aberrant in \% $(\mathrm{G}+\mathrm{C})$ are known, in Chromobacterium and in Agrobacterium (De Ley \& Van Muylem, 1963; De Ley, 1964).

\section{Pseudomonas}

The strains 'rubescens' 519 and 'pavonacea' 533 fall completely outside the main group, since their DNA is almost completely different. They differ more from Pseudomonas than does, for example, Escherichia. We propose to remove them from the genus Pseudomonas. Their \% $(\mathrm{G}+\mathrm{C})$ and physiological properties suggest a

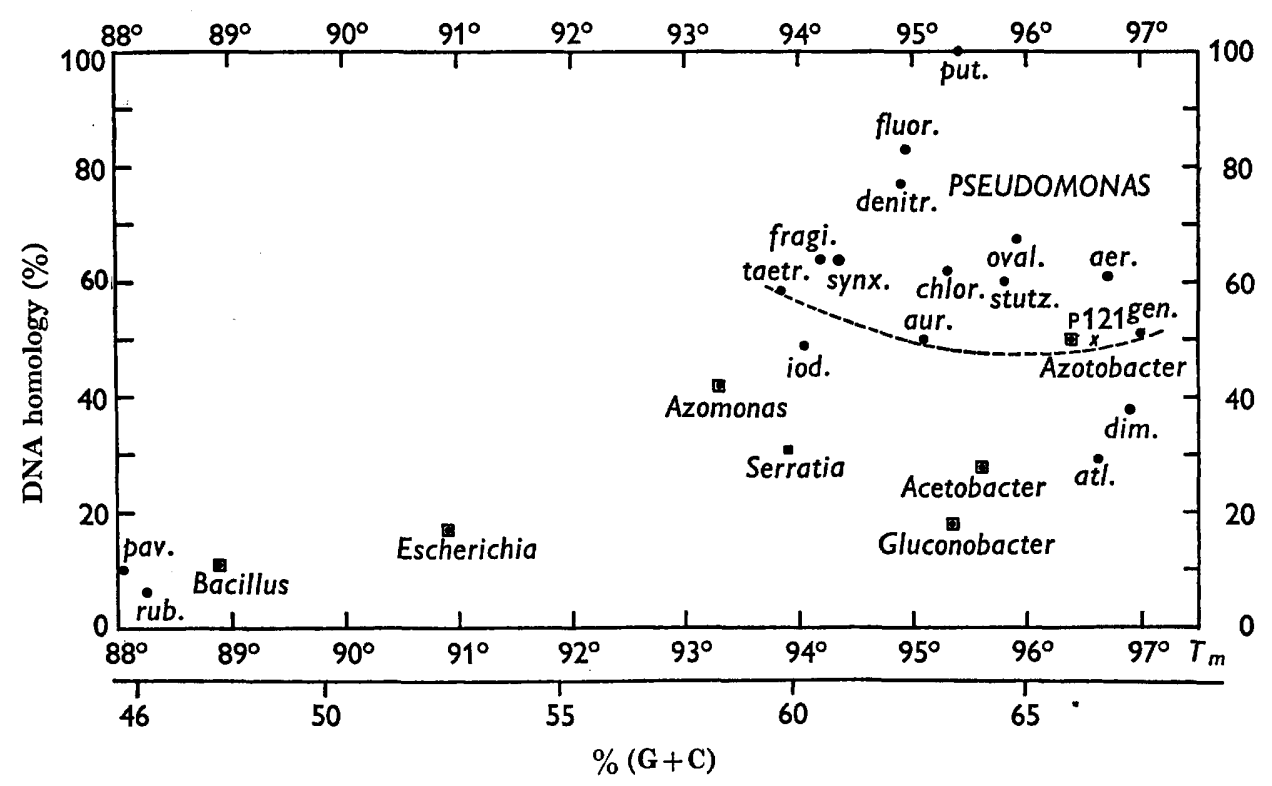

Fig. 3. Relatedness within the pseudomonas group and between the pseudomonads and a few other genera on the basis of DNA base composition and DNA homology (hybridization relative to $P$. putida 520). Symbols and abbreviations as in Figs. 1 and 2.

possible relationship with Vibrio which might be worth investigating. All the other strains form one broad group in which the strains are clearly separated. Since each strain is proposed as a species centre on the basis of numerical analysis (Lysenko, 1961), the present results indicate that-in contrast to $X$ anthomonas species differentiation in Pseudomonas may be justified. Since DNA-homology of the three doubtful cases ( $\boldsymbol{P}$. iodinum, $\boldsymbol{P}$. atlantica and $\boldsymbol{P}$. diminuta) is small, their inclusion in $P$ seudomonas is open to doubt. In fact they are about as far removed from $\boldsymbol{P}$. fluorescens as, for example, Serratia, Acetobacter, Rhizobium and Azotobacter. The strain 'rimaefaciens' PR 107, previously of uncertain generic status, appears to belong to Pseudomonas.

Previously we found that about $60-80 \%$ of Xanthomonas-DNA is identical to Pseudomonas-DNA (De Ley \& Friedman, 1965). The reverse is also true since 45-73\% of Pseudomonas fluorescens-DNA is identical with Xanthomonas-DNA. 
Figure 2 confirms Fig. 1 : in relation to $P$. fuorescens all xanthomonads form one tight cluster. They share about as much DNA with $\boldsymbol{P}$. fluorescens as do, for example, $\boldsymbol{P}$. geniculata or $\boldsymbol{P}$. aeruginosa. Therefore, there seems to be no reason to keep the xanthomonads in a separate genus and we propose to gather them in a single genetic species Pseudomonas campestris. It may be recalled that the creation of the genus-name Xanthomonas (Dowson, 1939) was not inspired by genetic data, but by the desire to group together the yellow-pigmented, necrotic phytopathogenic pseudomonads.

Phenotypically non-expressed DNA in Pseudomonas. It is not known whether all or only part of bacterial DNA is phenotypically expressed. It is conceivable that a certain fraction would have no genetic function as for example, nonsense DNA, and unused genes. Comparison of taximetric similarity of characters and DNA homology of the same strains might provide an answer. If homologous, phenotypically nonexpressed DNA is present, DNA homology will be higher than the similarity value. Such a comparison is made in Table 3. In 21 out of 30 cases DNA homology is not higher than the taximetric similarity. In many of the remaining 9 cases the difference lies within the limit of sensitivity of the methods. Therefore it seems that in most cases all DNA is used for phenotypic expression and that unused genes either do not exist or are rather scarce.

Imperfection of numerical analysis. In spite of its considerable advance over usual classification, taximetric analysis still deals with only a small part of the genome. Therefore occasional imperfections in its conclusions can be expected. It was previously (De Ley \& Van Muylem, 1963) pointed out that the yellow-pigmented marine Cytophaga-like bacteria fall into widely divergent $\%(G+C)$ groups. The present paper provides another example with the strains rubescens and pavonacea. A classification based on $\%(\mathrm{G}+\mathrm{C})$ and DNA homology appears to us to be more logical.

Relatedness of some other genera to Pseudomonas (Figs. 2 and 3). Genera such as Gluconobacter, Acetobacter, Serratia and Escherichia have some 20-30\% DNA similarity with Pseudomonas. They would have some 2000 cistrons in common with it. Rhizobium, Azotobacter and Azomonas appear to be more closely related to Pseudomonas than expected, since 40-56\% of their DNA seems to be Pseudomonaslike. Similarly, Serratia might be more closely related to Pseudomonas than expected. The chromosome of Bacillus is almost entirely different.

One of us (J.D.L.) is indebted to the Centre National de Biochimie et de Biologie Moléculaire for research and personnel grants. Another (I.W.P.) is indebted to the Patrimonium of the University of Gent for a study grant. We are indebted to the institutes and individuals who kindly sent us the strains, and to Dr M. Mandel, Texas, Medical Centre Houston, Texas, for a gift of phosphodiesterase.

\section{REFERENCES}

Baillie, A., Hodgkiss, W. \& Norris, J. R. (1962). Flagellation of Azotobacter spp. as demonstrated by electron microscopy. J. appl. Bact. 25, 116.

Bergey's Manual of Determinative Bacteriology. (1957). Ed. by R. S. Breed, E. G. D. Murray and N. Smith. Baltimore: Williams and Wilkins Co.

Bolton, E. T. \& McCarthy, B. J. (1962). A general method for the isolation of RNA complementary to DNA. Proc. natn. Acad. Sci., U.S.A. 48, 1390. 
Catalogue of Cultures, Czechoslovak Collections of Micro-organisms, Brno, 1964.

Colwell, R. R. \& MANDEL, M. (1964). Adansonian analysis and deoxyribonucleic acid base composition of some Gram-negative bacteria. J. Bact. 87, 1412.

Colwell, R. R. \& Mandel, M. (1965). Adansonian analysis and deoxyribonucleic acid base composition of Serratia marcescens. J. Bact. 89, 454.

De LEY, J. (1964). Effect of mutation on DNA-composition of some bacteria. Antonie van Leeurvenhoek, 30, 281.

DE LEY, J. (1965). DNA base composition of Klebsiella rubiacearum. Antonie van Leeureenhoek, 31, 203.

De Ley, J. \& Friedman, S. (1965). Similarity of Xanthomonas and Pseudomonas deoxyribonucleic acid. J. Bact. 89, 1306.

De Ley, J. \& RAsSer, A. (1965). DNA base composition, flagellation and taxonomy of the genus Rhizobium. J. gen. Microbiol. 41, 85.

De Ley, J. \& Schell, J. (1963). Deoxyribonucleic acid base composition of acetic acid bacteria. J. gen. Microbiol. 33, 243.

De LEY, J. \& VAN MuYlem, J. (1963). Some applications of deoxyribonucleic acid base composition in bacterial taxonomy. Antonie van Leeurwenhoek, 29, 344.

Doty, P., Marmur, J.\& Sueoka, N. (1959). The heterogeneityin properties and functioning of deoxyribonucleic acids. Brookhaven Symp. Biol. 12, 1.

Dowson, W. J. (1939). On the systematic position and generic names of the Gram negative bacterial plant pathogens. Zentbl. Bakt. (2 Abt. Ong.), 100, 177.

Friedman, S. \& De Ley, J. (1965). 'Genetic species' concept in Xanthomonas. J. Bact. $89,95$.

Hoyer, B. H., McCarthy, B. J. \& Bolton, E. T. (1964). A molecular approach in the systematics of higher organisms. Science, 144, 959.

Lysenko, O. (1961). Pseudomonas-an attempt at a general classification. J. gen. Microbiol. 25, 379.

McCarthy, B. J. \& Bolton, E. T. (1963). An approach to the measurement of genetic relatedness among organisms. Proc. nat. Acad. Sci., U.S.A. 50, 156.

Marmur, J. (1961). A procedure for the isolation of deoxyribonucleic acid from microorganisms. J. mol. Biol. 3, 208.

Marmur, J. \& Doty, P. (1962). Determination of the base composition of deoxyribonucleic acid from its thermal denaturation temperature. J. mol. Biol. 5, 109.

Marmur, J., Falkow, S. \& Mandel, M. (1963). New approaches to bacterial taxonomy. Annu. Rev. Microbiol. 17, 329.

Starr, M. P. \& Stephens, W. L. (1964). Pigmentation and taxonomy of the genus Xanthomonas. J. Bact. 87, 293. 